Purpose. To study the content of the vascular cell adhesion molecule VCAM-1 in the blood at different stages of the DRP.

Material and methods. The research was carried out with 64 patients ( 95 eyes) with at type 2 diabetes mellitus (T2DM), metabolic syndrome (MS) and DRP (age $61.55 \pm 2.37$ years old, length of diabetes $11.23 \pm 2.11$ years, level of HbA1C $9.89 \pm 0.78 \%$, BMI $34.55 \pm 3.75 \mathrm{~kg} / \mathrm{m} 2$ ), who were divided into 3 groups depending on the stage of DRP. Exclusion criteria for this study were: type 1 diabetics, mental disorders, age less than 18 years, severe comorbidities such as congestive heart failure, liver disease, malignancy, inflammatory process, pregnancy, or any factor affecting body weight such as hypothyroidism, corticosteroids (Cushing's syndrome), or contraceptives. Written informed consent was obtained from all subjects prior to the inclusion into the study. The ANOVA and regression analysis were used as statistical analysis.

Results. The highest value of the VCAM-1 level of blood was in the nonproliferative stage of DRP $(3.45 \pm 0.39$ $\mathrm{pg} / \mathrm{ml})$. Regardless of the stage of the DRP, a significant direct linear relationship was found between VCAM- 1 and fibrinogen of the blood $\left(\mathrm{r}=0.59, \mathrm{R}^{2}=35.1 \%, \mathrm{p}=0.01\right)$. The tendency in the direct dependence of the VCAM- 1 content and the duration of T2DM was revealed $\left(r=0.25, \mathrm{R}^{2}=6.5 \%, \mathrm{p}=0.05\right)$.

Conclusions. Possible participation of VCAM-1 together with fibrinogen in the formation of leukostasis and capillary occlusion, especially in the nonproliferative stage of DRP was traced.

Key words: diabetic retinopathy, VCAM-1, type 2 diabetes mellitus, metabolic syndrome.

Стаття надійшла до редакції 17.01.2018 p.

\title{
МОРФОМЕТРИЧНІ ОСОБЛИВОСТІ СУДИННОЇ ОБОЛОНКИ ОКА У ПАЦІЄНТІВ 3 ПРОГРЕСУЮЧОЮ МІОПІЄЮ ЗА ДАНИМИ SS-ОПТИЧНОÏ КОГЕРЕНТНОÏ ТОМОГРАФІЇ-АНГІОГРАФІЇ
}

\begin{abstract}
Метою дослідження було вивчення морфометричних змін судинної оболонки у задньому сегменті ока у пацієнтів $з$ прогресуючою міопією за даними Swept Source-оптичної когерентної томографії-ангіографії (SS-OKТА). Під спостереженням знаходились 50 пацієнтів (100 очей) 3 різними темпами прогресування міопії та 20 здорових дітей (40 очей) з еметропією.

У пацієнтів зі швидким прогресуванням міопії виявлено збільшення товщини сітківки в центрі фовеа порівняно з еметропами та зменшення товщини хоріоідеї в центрі фовеа і у папіломакулярній ділянці порівняно як із еметропами, так і з міопами 3 повільним прогресуванням міопії. При прогресуванні міопії встановлено нерівномірне зменшення товщини хоріоідеї, яке проявляється у достовірному збільшенні ретинально-хоріоідального коефіцієнта на ділянці між центром фовеа та диском зорового нерва, що у комплексі морфологічних змін заднього сегмента міопічного ока може сприяти розвитку регіонарних гемодинамічних порушень.

Ключові слова: прогресуюча міопія, судинна оболонка, оптична когерентна томографія.
\end{abstract}

Структурні особливості сітківки в макулярній та перипапілярній ділянках очного дна досить добре вивчені як при прогресуючій, так і при високій ускладненій міопії $[1,3]$. Багато праць присвячено вивченню морфометричних змін сітківки при змінах топографії макули, зумовленої формуванням задньої міопічної стафіломи [8]. Але чималий інтерес викликає роль змін судинної оболонки у міопічному оці, оскільки, згідно існуючих теорій патогенезу міопії, саме пору- шення трофіки заднього сегмента ока призводить до розвитку органічних змін сенсорного апарата ока та зниженню зорових функцій.

Сучасні методи візуалізації оболонок ока та судинного русла дозволяють вивчати морфологічні та морфометричні зміни заднього сегмента очного яблука на високому роздільному рівні. Одним із таких методів $\epsilon$ оптична когерентна томографія з ангіографією(ОКТА). Оцінка товщини судинної оболонки $з$ використанням 
сучасних методів дослідження $є$ досить актуальною та перспективною при різноманітній патології ока, зокрема при первинній відкритокутовій глаукомі та центральній серозній хоріоретинопатії $[6,11]$. У сучасній офтальмології навіть сформована група так званих пахіхоріоідальних захворювань, при яких на тлі потовщення судинної оболонки відзначається порушення архітектоніки сітківки. Спектр пахіхоріоідальної патології включає в себе пахіхоріоідальну пігментну епітеліопатію, центральну серозну хоріоретинопатію, пахіхоріоідальну неоваскулопатію та поліпоїдну хоріоідальну васкулопатію $[2,5]$. На думку багатьох дослідників, інформація про стан хоріоідеї при запальній та дегенеративній патології дозволить розширити наукові дані про патогенез багатьох захворювань ока.

Висока проникна здатність ОКТА надає можливості оцінювати не тільки архітектоніку судинного русла сітківки та хоріоідеї, але й, в окремих випадках, оцінювати стан ретробульбарних судин при високій осьовій міопії, що супроводжується вираженими атрофічними змінами усіх оболонок ока [7]. Згідно даних літератури, актуальним є не лише визначення структурних особливостей судинної оболонки ока та сітківки при міопії, але й вивчення відмінностей цих морфометричних характеристик при міопічній макулопатії [12].

На підставі вищенаведеного метою нашого дослідження $€$ вивчення морфометричних змін судинної оболонки у задньому сегменті ока у пацієнтів 3 прогресуючою міопією за даними Swept Source-оптичної когерентної томографії-ангіографії (SS-OKTA).

Матеріали та методи. Під спостереженням на клінічній базі кафедри офтальмології в Офтальмологічному медичному центрі Університетської клініки Одеського національного медичного університету знаходились 50 пацієнтів із прогресуючою міопією у віці 8-15 років та 20 однолітків 3 еметропією. Групи спостереження

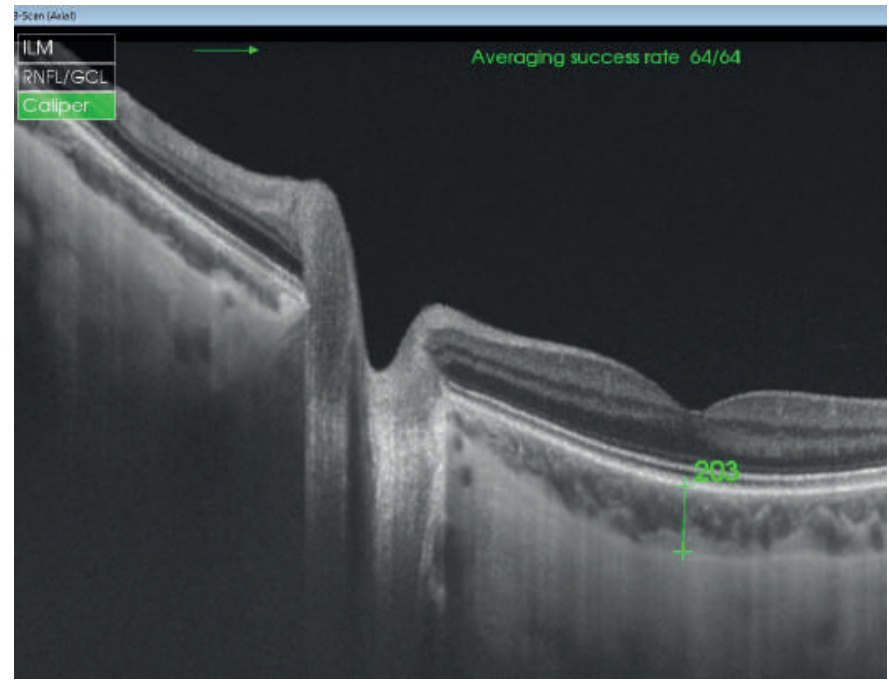

Puc. 1. ОКТ-скан, отриманий у режимі 3D Wide(H) $(12.0 \mathrm{~mm} \times 9.0 \mathrm{~mm})$. Приклад вимірювання субфовеолярної товщини судинної оболонки були сформовані згідно темпів прогресування міопії. Так, 1-а група - 25 пацієнтів (50 очей) із повільним темпом прогресування міопії (до 1.0 дптр за рік); 2-а група - 25 пацієнтів (50 очей) зі швидким темпом прогресування міопії (понад 1.0 дптр за рік); 3-я група - 20 здорових дітей (40 очей) з еметропією. Пацієнти 1-ї та 2-ї груn мали міопію від -3.0 дптр до -6.0 дптр. Розподіл пацієнтів обох груп за ступенем рефракції був порівнянний. Пацієнти 1-ї групи переважно мали рефракційний тип міопії на відміну від пацієнтів 2-ї групи, котрі мали осьову міопію. Таким чином, передньозадній розмір у 1-ц̌ груni коливався від 23.1 мм до 24.3 мм, у 2-й групі - від 24.2 мм до 25.7 мм. Усім пацієнтам проведено стандартне офтальмологічне обстеження (візометрія, рефрактометрія, офтальмометрія, біомікроскопія, УЗ-біометрія, офтальмоскопія).

Вивчення морфологічних особливостей сітківки та судинної оболонки виконували методом SS-OKTA на апараті "DRI Triton Plus" у режимі “3D Wide (H) (12.0 $\mathrm{mm} \times 9.0 \mathrm{~mm}$ ) з подальшим морфометричним аналізом згідно розробленого алгоритму, який, окрім визначення товщини сітківки, включав вимірювання товщини судинної оболонки в центрі фовеа, а також у точці М, яку знаходили у папіломакулярному сегменті отриманого скану на середині відстані від центру фовеа до краю диска зорового нерва по крайній межі гіперрефлективного шару пігментного епітелію сітківки (рис. 1, рис. 2). Товщина сітківки визначалась по відстані між внутрішньою пограничною мембраною та шаром пігментного епітелію сітківки. Товщина судинної оболонки визначалась як відстань між мембраною Бруха та гіперрефлективною смугою, котра відповідає внутрішній поверхні склери. Для вивчення співвідношення товщини сітківки до товщини судинної оболонки було запропоновано використання ретинально-хоріоідального коефіцієнта, котрий обчислювався як арифметичне співвідношення показань товщин зазна-

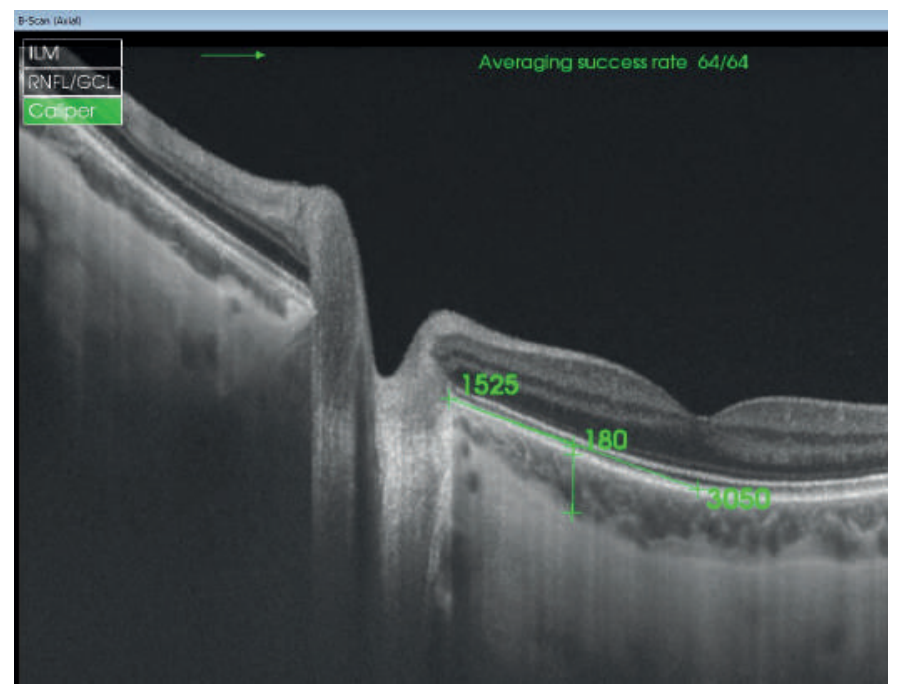

Puc. 2. ОКТ-скан, отриманий у режимі 3D Wide(H) $(12.0 \mathrm{~mm} \times 9.0 \mathrm{~mm})$. Приклад вимірювання товщини судинної оболонки в папіломакулярному сегменті 
Морфометричні показники сітківки та хоріоідеї у паціснтів з міопією за даними SS-OKTA

Таблиия

(n-кількість очей, $\mathrm{M} \pm \mathbf{m}$, мкм)

\begin{tabular}{|c|c|c|c|}
\hline Показник & $1(n=50)$ & $2(n=50)$ & $3(n=40)$ \\
\hline Товщина сітківки в центрі фовеа, мкм & $195,2 \pm 3,7$ & $206,6 \pm 2,5^{* 1}$ & $190,1 \pm 2,6$ \\
\hline Товщина сітківки в точці М, мкм & $321,5 \pm 4,0$ & $319,3 \pm 2,5$ & $318,2 \pm 2,8$ \\
\hline Товщина хоріоідеї в центрі фовеа, мкм & $272,9 \pm 11,0$ & $237,3 \pm 9,2 * 1,2$ & $301,4 \pm 9,7$ \\
\hline Товщина хоріоідеї в точці М, мкм & $198,6 \pm 8,1$ & $178,2 \pm 5,3 * 1,2$ & $218,3 \pm 9,2$ \\
\hline $\begin{array}{c}\text { Ретинально-хоріоідальний коефіцієнт у центрі } \\
\text { фовеа }\end{array}$ & $0,77 \pm 0,03$ & $0,95 \pm 0,04 * 1,2$ & $0,69 \pm 0,03$ \\
\hline Ретинально-хоріоідальний коефіціснт у точці М & $1,89 \pm 0,09 * 1$ & $2,13 \pm 0,07 * 1,2$ & $1,47 \pm 0,08$ \\
\hline
\end{tabular}

Примітки:

* 1 - $<<0,05$ у порівнянні з еметропами (група 3-я);

*2 - $<<0,05$ порівняння пацієнтів 1-ї та 2-ї груп

чених оболонок. Ретинально-хоріоідальний коефіцієнт визначався у двох топографічних ділянках: у центрі фовеа та у точці М, котра розцінювалась як центр папіломакулярної ділянки. Статистичне опрацювання отриманих даних проводили із використанням дисперсійного аналізу, у разі коли нульова гіпотеза відкидалась, застосовували критерій Ньюмена-Кейлса.

Результати та їх обговорення. Загальновідомо, що при формуванні задньої міопічної стафіломи спостерігаються виражені зміни топографії заднього полюса ока, що спричинює порушення архітектоніки його оболонок, зокрема сітківки. Найзначніші зміни виникають у макулі та перипапілярних сегментах. Тому в ході нашої роботи ми провели вивчення морфометричних показників сітківки та судинної оболонки - як у центрі макули, так і в центральній ділянці папіломакулярної зони. В результаті проведених досліджень встановлено, що товщина сітківки в центрі фовеа була більша у пацієнтів 2-ї групи спостереження порівняно з еметропами того ж віку та складала в середньому 206,6 2,5 мкм ( $<0,05)$. Статистично достовірних відмінностей у пацієнтів зі швидким прогресуванням міопії порівняно 3 пацієнтами 1-ї групи не виявлено (табл.). Також відсутні були відмінності товщини сітківки у точці М у всіх обстежених хворих mpьox груn спостереження. Отримані дані узгоджуються з існуючими даними літератури, які свідчать, що зі збільшенням ступеня короткозорості спостерігається тенденція до збільшення товщини сітківки саме в фовеальній зоні [4]. При цьому збільшення товщини сітківки проходить нерівномірно, а саме: найбільш виражено - у верхньому та нижньому сегментах на відміну від назального та темпорального. Це може бути пов'язано зі збільшенням аксіальної довжини ока при міопії, що призводить до механічного розтягування склери, а це, в свою чергу, призводить до розтягування сітківки у центральній ямці, яка $€$ однією з точок щільної фіксації сітківки [13].

Товщина хоріоідеї у пацієнтів зі швидким прогре- суванням міопії та більш високими іiі ступенями в

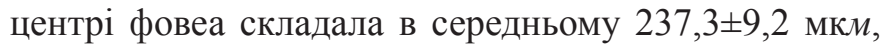
що було менше, ніж у еметропів та пацієнтів 3 відносно повільним прогресуванням міопії $(\mathrm{p}<0,05)$. Окрім того, заслуговує на увагу той факт, що зменшення товщини хоріоідеї спостерігалось також і у точці М у пацієнтів 2-ї групи. Відомо, що у нормі товщина субфовеолярної судинної оболонки за даними ОКТ досліджень поступово збільшується до підліткового віку [9]. Але при міопії дійсно встановлено виражене та нерівномірне зменшення товщини судинної оболонки, і автори пов'язують це також зі збільшенням аксіальної довжини ока [10]. Отримані нами дані узгоджуються з існуючими даними літератури. На нашу думку, при збільшенні аксіальної довжини ока, на відміну від фовеоли, де відбувається механічне натягування сітківки, судинна оболонка при подовженні осі навпаки стоншується, оскільки не має вираженої фіксації та не зазнає розтягування. Зменшення товщини судинної оболонки може супроводжуватися зменшенням щільності судин в одиниці об'єму, що може бути морфологічним субстратом розвитку порушень гемодинаміки у міопічному оці. Це додатково створює передумови для порушення трофіки оболонок ока та призводить до дистрофічних змін сітківки.

Відомо, що зменшення товщини хоріоідеї при міопії відбувається нерівномірно та у значній мірі залежить від формування міопічної стафіломи [14]. В результаті проведених досліджень встановлена наявність достовірних відмінностей ретинально-хоріоідального коефіцієнта, що характеризує співвідношення товщини сітчастої та судинної оболонок ока, у пацієнтів зі швидким прогресуванням міопії, а саме - у пацієнтів 2-ї групи, показник мав більші значення, ніж у еметропів для товщин у центрі фовеа, та більше ніж у еметропів та пацієнтів 1-ї групи у точці М. Таким чином, визначення даного коефіцієнта саме у точці М, котра відповідає центру папіломакулярної зони, може бути запропоноване для прогнозування 
виникнення стоншення судинної оболонки при прогресуванні осьової міопії.

На підставі отриманих даних щодо морфометричних змін судинної оболонки при прогресуванні міопії перспективним напрямком у розробці патогенетично обгрунтованих методів запобігання розвитку дистрофічних ускладнень міопії $є$ пошук засобів, спрямованих не лише на поліпшення сполучнотканинного каркасу склери, але й ефективних методів поліпшення структури та функції судинної оболонки ока, що безперечно буде сприяти поліпшенню трофіки сітківки.

\section{Висновки}

1. У пацієнтів зі швидким прогресуванням міопії спостерігається збільшення товщини сітківки в центрі фовеа порівняно з еметропами та зменшення товщини хоріоідеї в центрі фовеа і у папіломакулярній ділянці порівняно як з еметропами, так і з міопами 3 повільним прогресуванням міопії.

2. При прогресуванні міопії встановлено нерівномірне зменшення товщини хоріоідеї, що проявляється у достовірному збільшенні ретинально-хоріоідального коефіцієнта на ділянці між центром фовеа та диском зорового нерва, що у комплексі морфологічних змін заднього сегмента міопічного ока може сприяти розвитку регіонарних гемодинамічних порушень.

\section{Література}

1. Горбатюк Т. Л. Морфоструктурные особенности зрительного нерва и перипапиллярных волокон у детей с миопией / Т. Л. Горбатюк, И. М. Бойчук // Офтальмол. журн. - 2011. - № 1. - С. 41-44.

2. Akkaya S. Spectrum of pahychoroid diseases / S. Akkaya // Int. Ophthalmol. - 2017. - DOI: 10.1007/s10792-017-0666-4.

3. Atta Allah H. R. Assessment of Posterior Segment Using Spectral Domain OCT in Highly Myopic Eyes / H. R. Atta Allah, I. A. N. Omar, A. S. Abdelhalim // Open Ophthalmol. J. - 2017. - № 11. - P. 334-345.

4. Cheng S. C. Retinal thickness in myopic and nonmyopic eyes / S. C. Cheng, C. S. Lam, M. K. Yap // Ophthalmic Physiol. Opt. - 2010. - Vol. 30. - P. 776-784.

5. Dolz-Marco R. Macularretinal and choroidal thickness in unilateral relentless placoid chorioretinitis analyzed by swept-source optical coherence tomography / R. Dolz-Marco, A. Rodríguez-Ratón, P. FernándezMartínez [et al.] // J. Ophthalmic Inflamm. Infect. 2014. - Vol. 4. - P. 24.

6. Li X. Difference of uveal parameters between the acute primary angle closure eyes and the fellow eyes / X. Li, W. Wang, W. Huang [et al.] // Eye (Lond). 2018. - DOI: 10.1038/s41433-018-0056-9.

7. Maruko I. Detection of retrobulbar blood vessels in optical coherence tomography angiographic images in eyes with pathologic myopia/I. Maruko, H. Koizumi, T. Hasegawa [et al.] // Am. J. Ophthalmol. Case Rep. - 2016. - № 4. - P. 74-77.

8. Ohno-Matsui K. Peri-dome Choroidal Deepening in Highly Myopic Eyes With Dome-Shaped Maculas / K. Ohno-Matsui, Y. Fang, K. Uramoto [et al.] // Am. J. Ophthalmol. - 2017. - Vol. 183. - P. 134-140.

9. Read S. A. Choroidal thickness in childhood/S. A. Read, M. J. Collins, S. J. Vincent [et al.] // Invest. Ophthalmol. Vis. Sci. - 2013. - Vol. 54, № 5. - P. 3586-3593.

10. Read S. A. Choroidal thickness in myopic and nonmyopic children assessed with enhanced depth imaging optical coherence tomography / S.A. Read, M.J. Collins, S.J. Vincent [et al.] // Invest. Ophthalmol. Vis. Sci. - 2013. - Vol. 54, № 12. - P. 7578-7586.

11. Saito $W$. Choroidal thickness changed in a patient diagnosed with central serous chorioretinopathy during follow-up for pahychoroid pigment epitheliopathy / W. Saito, Y. Hashimoto, K. Hirooka [et al.] // Retin Cases Brief Rep. - 2018. - DOI: 10.1097/ ICB.0000000000000728.

12. Teberik K. Retinal and Choroidal Thickness in Patients with High Myopia without Maculopathy / K. Teberik, M. Kaya // Pak. J. Med. Sci. - 2017. Vol. 33, № 6. - P. 1438-1443.

13. Wu P. C. Assessment of macular retinal thickness and volume in normal eyes and highly myopic eyes with third-generation optical coherence tomography / P. C. Wu, Y.J. Chen, C.H. Chen [et al.] // Eye (Lond). - 2008. - Vol. 22. - P. 551-555.

14. Zhou Ling Xiao. The relationship between scleral staphyloma and choroidal thinning in highly myopic eyes / Ling Xiao Zhou, Lei Shao, Liang Xu [et al.] // The Beijing Eye Study. Sci Rep. - 2017. - Vol. 7. - P. 9825.

\section{МОРФОМЕТРИЧЕСКИЕ ОСОБЕННОСТИ СОСУДИСТОЙ ОБОЛОЧКИ ГЛАЗА У ПАЦИЕНТОВ С ПРОГРЕССИРУЮЩЕЙ МИОПИЕЙ ПО ДАННЫМ SS-ОПТИЧЕСКОЙ КОГЕРЕНТНОЙ ТОМОГРАФИИ-АНГИОГРАФИИ}

\section{Н. А. Ульянова, С. И. Бурдейный}

Целью исследования было изучение морфометрических изменений сосудистой оболочки в заднем сегменте глаза у пациентов с прогрессирующей миопией по данным Swept Source-оптической когерентной томографии-ангиографии (SS-OKTA). Под наблюдением находились 50 пациентов (100 глаз) с различными темпами прогрессирования миопии и 20 здоровых детей (40 глаз) с эмметропией. 
У пациентов с быстрым прогрессированием миопии выявлено увеличение толщины сетчатки в центре фовеа в сравнении с эмметропами и уменьшение толщины хориоидеи в центре фовеа и в папилломакулярном участке по сравнению с эмметропами и миопами с медленным прогрессированием миопии. При прогрессировании миопии установлено неравномерное уменьшение толщины хориоидеи, которое проявляется в достоверном увеличении ретинально-хориоидального коэффициента на участке между центром фовеа и диском зрительного нерва, что в комплексе морфологических изменений заднего сегмента миопического глаза может способствовать развитию регионарных гемодинамических нарушений.

Ключевые слова: прогрессирующая миопия, сосудистая оболочка, оптическая когерентная томография.

\title{
MORPHOMETRIC FEATURES OF THE CHOROID IN PATIENTS WITH PROGRESSIVE MYOPIA ACCORDING TO THE SS-OPTICAL COHERENT TOMOGRAPHY-ANGIOGRAPHY
}

\author{
N. A. Ulyanova, S. I. Burdeinyi \\ Odesa National Medical University of the Ministry of Public Health of Ukraine \\ Odesa, Ukraine
}

The aim of the study was to investigate the morphometric changes in the choroid of the posterior segment of the eye in patients with progressive myopia according to Swept Source-optical coherence tomography-angiography (SS-OCTA). There were 50 patients (100 eyes) under observation with different scores of myopia progression and 20 healthy children (40 eyes) with emmetropy.

In patients with rapid progression of myopia, an increase in the thickness of the retina in the center of the fovea was observed in comparison with emmetropes, and a decrease in the thickness of the choroid in the center of the fovea and in the papillomacular area compared with emmetropes and myopes with slow progression of myopia. With the progression of myopia, an uneven decrease in the thickness of the choroid has been established, which manifests itself in a significant increase in the retinal-choroidal coefficient between the center of the fovea and the optic nerve disc, which, in a complex of morphological changes in the posterior segment of the myopic eye, may contribute to the development of regional hemodynamic disorders.

Key words: progressive myopia, choroid, optical coherence tomography.

Стаття надійшла до редакції 16.03.2018 р.

Т. Є. Цибульська, Н. Г. Завгородня, О. Є. Пашкова

Запорізький державний медичний університет МОЗ України

- м. Запоріжжя, Україна

\section{ОСОБЛИВОСТІ БІОМЕТРИЧНИХ ПОКАЗНИКІВ ЗОРОВОГО АНАЛІЗАТОРА У ДІТЕЙ ІЗ НАБУТОЮ МІОПІЄЮ, АСОЦІЙОВАНОЮ ІЗ СИНДРОМОМ НЕДИФЕРЕНЦІЙОВАНОЇ ДИСПЛАЗІЇ СПОЛУЧНОЇ ТКАНИНИ}

Мета роботи: оцінити біометричні показники зорового аналізатора у дітей із набутою міопією, асоційованою з синдромом недиференційованої дисплазії сполучної тканини. Встановлено деякі особливості біометричних показників зорового аналізатора у дітей з міопією на тлі сполучнотканинної дисплазії, які виявляються у зниженні сили заломлення рогівки в середньому на 4,6 \%, збільшенні радіуса кривизни на 5,3 \% та діаметра рогівки на 7,2 \%, збільшенні глибини передньої камери ока в середньому на 5,2 \%, сагітальної довжини склоподібного тіла в середньому на 9,2 \% та аксіальної довжини ока в середньому на $4,2 \%$.

Ключові слова: міопія, діти, біометричні показники, дисплазія сполучної тканини. 